\title{
The Implementation of Critical-Thinking Skills and Teaching Strategies by Social Studies Teachers in Kuwait and the Difficulties They Face
}

\section{* Dr. Maadi Mahdi Alajmi}

\section{Abstract}

This study investigates how social studies teachers in Kuwait implement critical-thinking skills, teaching strategies, and assessment techniques. And to identify the challenges they face. The research adopts the descriptive method as the most appropriate for this study, describing a phenomenon and reaching a generalization by analyzing and reviewing previous research. (Creswell, 2021). A questionnaire was distributed to 638 social studies teachers in Kuwaiti schools and 116 instructional supervisors to conduct the study. The study's findings indicated a lack of teachers' understanding of critical-thinking skills, a weakness in applying those skills to instructional strategies, a lack of assessment techniques, and difficulties confronting those who taught critical-thinking skills. Based on the study results, recommendations were made regarding the development of pre-senvice teacher preparation programs, attention to in-senvice teacher training, social studies curricula development, and their inclusion of critical thinking skills, activities, and strategies. The study also recommended that decisionmakers overcome all teachers' difficulties to improve critical thinking and achieve the desired educational objectives.

Key Words: critical-thinking skills, critical-thinking instructional strategies, critical-thinking assessment, social studies, critical-thinking difficulties

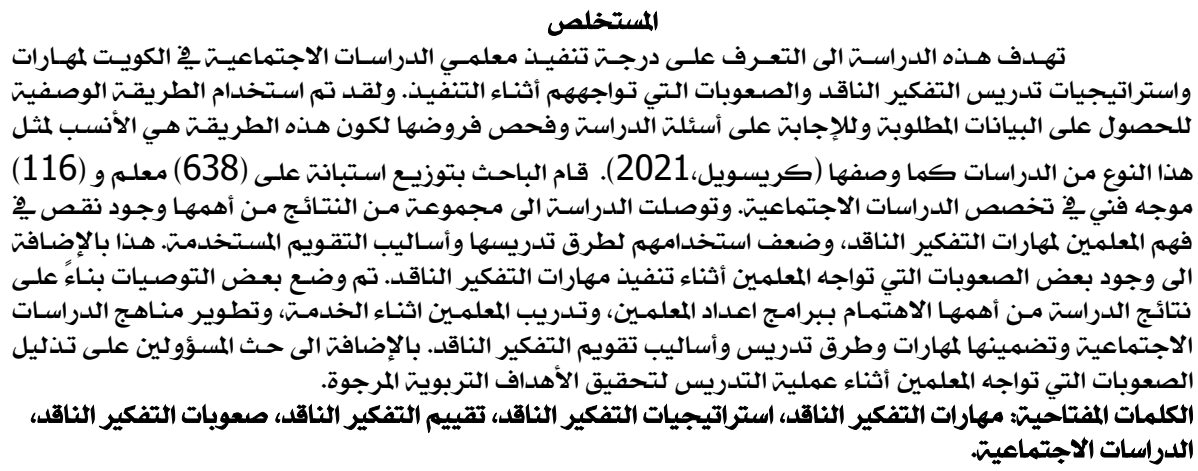

\footnotetext{
* Associate Professor, Curiculum, and Instruction Department.College of Education-Kuwait University. ORCID: 0000-0002-3350-3048

dmaadi1@gmail.com
} 


\section{Introduction}

Educators have widely acknowledged the importance of critical thinking as an educational goal. According to Arifan (2020), integrating critical-thinking skills, one of the $21^{\text {st }}$ century's essential skills, into the curricula at all grades and implementing these curricula appropriately is crucial for raising new generations who can think critically.

Teaching critical thinking has always been an essential mission for social studies education; thus, it has been considerable attention in the social studies literature. However, despite the amount of literature and the awareness that this topic has received, the available literature indicates that critical thinking in social studies classrooms has been problematic. Many scholars have stated that a prevailing characteristic of the social studies classroom has been the absence of thought or the teaching of thinking (Celik, 2021)).

This study explores the implementation of critical-thinking skills, instructional strategies, and assessment methods by social studies teachers in Kuwait and the difficulties they face in doing so. In addition, this research aims to draw the attention of those responsible for the educational process in Kuwait to the importance of critical thinking in the teaching of the social studies curricula. Finally, the study's aim is achieved by discovering the reality of teaching criticalthinking skills, gaining knowledge of the disadvantages and obstacles, and proposing appropriate solutions to develop the educational process in Kuwait.

\section{Literature review}

\subsection{Definition of critical thinking}

Critical thinking has been variously defined in the literature. However, thinking critically is the willingness, desire, and disposition to base one's actions and beliefs on causes. (Celik, 2021). It is a necessary competence required by citizens to participate in a modern, democratic society; it enables citizens to contribute to the community critically and consciously (Stanley, 2017),

(Warsah, Morganna \& Uyun, 2021). Another definition mentioned by Thonney and Montgomery (2019) is the process of conceptualizing, applying, analyzing, and evaluating information, experience, reflection, reasoning, or communication, as a guide to belief and action.

From previous definitions, critical thinkers should learn about an issue before beginning evaluation, refuse to make or accept conclusions without careful evaluation, analyze evidence carefully, detect bias and unsubstantiated evidence, 
distinguish between known and suspected, and evaluate objectively. In this context, a critic reviews and evaluates issues, ideas, processes, and experiences (Maksum, Widiana \& Marini, 2021).

\subsection{Skills for critical thinking}

Critical thinking (CT) includes analyzing arguments, making decisions, solving problems, judging, and evaluating. In addition, the process respects diverse viewpoints, a desire for knowledge, an attempt to determine the reasons, cognitive skills, and flexibility. (Liu, Yu, Lu, Wang, Zhu, \& Yang, 2021). According to Purnawati, Susanti, \& Rustamti (2021), a general list of skills applicable in almost any class would include recognizing and criticizing assumptions, giving reasons to support a conclusion, assessing degrees of likelihood and uncertainty, using analogies to solve problems, and incorporating isolated data into a broader framework. Fajrianti, Hartono \& Nugroho (2021) mentioned some essential skills associated with $\mathrm{CT}$, such as interpretation, analysis, inference, evaluation, explanation, and self-regulation. Samaras, Adkins \& White (2021) indicated that CT required aptitude in critical listening to others' views and opinions, distinguishing between fact and opinion, asking clear and easily understood questions, identifying underlying assumptions, determining hypotheses

from evidence, making appropriate use of persuasive techniques, and recognizing a variety of political, social, cultural, and personal perspectives. The skills defined by the Delphi study include interpretation, analysis, inference, evaluation, explanation, and self-regulation. (Silviariza, Sumarmi \& Handoyo, 2021).

According to Chen (2019), research, information, and technology skills include the following tasks: locate information, explore data, organize usable information forms, use computer-based technology and media/communication technology, interpret data, analyze data, synthesize information, and evaluate information.

\subsection{Critical-thinking instructional strategies}

Research has shown that learners begin developing critical-thinking competencies at an early age. Therefore, theory suggests that people can be taught to think critically, and teachers have been increasingly urged to provide instruction in critical-thinking skills. There is a large-scale agreement that student CT 
skills are essential and should be improved, and necessary work has been done defining those skills in state standards. However, the question remains about how best to teach these skills (Antonova, Pletyago \& Ostapenko, 2020). Students must be taught to transfer critical thinking to various contexts by being provided with opportunities to apply these skills in diverse contexts (Kayaalp, Meral, Şimşek \& ŞAHIN, 2020). Keleman, Rasul \& Jalaudin (2021) recommend basic critical-thinking skills courses and essential considerations within discipline-specific classes. This finding suggests that educators should integrate critical thinking instruction into regular academic content and teach general CT as a stand-alone component (Helbrle, Rapa \& Farago, 2020).

Teachers are urged to use constructivist learning methods, characterized as more student-centered than teacher-centered. Additional activities include classroom discussions, discussion groups, group work, fieldwork, problem-solving, multimedia use, pre-writing, hands-on activities, reflection and rewriting, stakeholder debates, debate competitions, brainstorming, scaffolding, and collaborative learning (Akinoglu \& Baykin, 2015; Hidayatul et al., 2020; Kozikoglu, 2019). According to Lennon (2017), strategies for teaching critical thinking have been classified as general, infusion, immersion, and mixed.

\subsection{Social studies and critical thinking}

The purpose of social studies instruction is to educate students to think critically and to create scholars who are advanced in problem-solving, decisionmaking, and thinking on a higher level within the community (Mendoza, 2021). Unfortunately, despite the advantages of teaching critical-thinking skills in social studies, the available literature indicates that social studies teaching has been unsuccessful and generally neglected (Nurhayati, Putranto, Marwa \& Purwowidodo, 2020). (Kopotun, Durdynets, Teremtsova, Markina \& Prisnyakova, 2020).

\section{Research Problem}

One of the most important goals of social studies is to develop students' critical thinking skills. Therefore, it is necessary to identify the types of critical thinking skills, teach them, and the evaluation methods used to ensure that students acquire them. This study seeks to determine how social studies teachers in Kuwait apply critical thinking skills and identify the strategies and evaluation methods and their difficulties when teaching them. 


\subsection{Study Questions}

The problem addressed in this study is represented in the following questions:

1. What critical-thinking skills are applied by social studies teachers in Kuwait?

2. What teaching strategies are used by social studies teachers to foster critical thinking skills?

3. What assessment techniques are used by social studies teachers when teaching critical-thinking skills?

4. What difficulties do social studies teachers face when teaching critical thinking skills?

\subsection{Research Hypotheses}

This study attempts to verify the following null hypotheses:

1. There are no significant differences at the level of significance (.05) between teachers and instructional supervisors regarding applying critical thinking skills due to occupation, gender, age, or experience.

2. There are no significant differences at the level of significance (.05) between teachers and instructional supervisors regarding strategies for teaching critical thinking skills due to occupation, gender, age, or experience.

3. There are no significant differences at the level of significance (.05) between teachers and instructional supervisors regarding critical thinking assessment due to occupation, gender, age, or experience.

4. There are no significant differences at the level of significance (.05) between teachers and instructional supervisors related to the difficulties in teaching critical thinking skills due to occupation, gender, age, or experience.

\section{Purpose of the study}

This study aims to identify the critical thinking skills applied by social studies teachers and determine the teaching methods and assessment techniques. In addition to identifying the difficulties, teachers face in teaching necessary thinking skills. 


\section{Significance of the study}

The results of this study will be helpful for both teachers and instructional supervisors to identify critical thinking skills, modern strategies in teaching them, and evaluation methods used to ensure that students acquire these skills. In addition, the developers of social studies curricula will also benefit from these results to build curricula that include critical thinking skills and methods of teaching them. Finally, the results of this study will also help decision-makers know the difficulties that teachers face when teaching critical thinking skills to work on overcoming them.

\section{Methodology and Procedures}

The research adopts the descriptive method as the most appropriate for this type of study. This method describes a phenomenon, reaching a generalization by analyzing and reviewing previous research (Creswell, 2021). To conduct the study, the researcher followed the following procedures:

1. Review the literature on critical thinking skills to identify their types, teaching strategies, and assessment methods.

2. Designing the questionnaire as the main instrument for data collection.

3. Testing and validating the questionnaire by consulting specialists in social studies curriculum and teaching methods.

4. Conducting a pilot study of 28 individuals for the research sample.

5. Ensure the validity and reliability of the research tool.

6. Distributing the questionnaire to the study sample.

7. Collecting and analyze the data by using the SPSS to discuss research questions and hypotheses.

8. Writing the results and recommendations of the study.

\subsection{The study population and sample}

According to the Ministry of Education (2019) statistics, social studies teachers reached 5445, 3745 are female, and 1700 are male. The number of instructional supervisors reached 741 , including 420 females and 321 males. A simple random sample was selected from the research population. The research sample consisted of 638 teachers (415 females and 223 males). And 116 instructional supervisors (69 females and 47 males). Therefore, the total sample members are 754 ( 492 females and 262 males). 
Table 1 shows the details of the demographic characteristics of the study sample.

Table 1: Demographic characteristics of the research sample

\begin{tabular}{|c|c|c|}
\hline Demographics & Determinants & Frequency/Percentage \\
\hline \multirow{2}{*}{ Occupation } & & \\
\cline { 2 - 3 } & Teacher & $638(11.7 \%)$ \\
\hline \multirow{2}{*}{ Gender } & Supervisor & $116(15.7 \%)$ \\
\cline { 2 - 3 } & Female & $492(65 \%)$ \\
\hline \multirow{2}{*}{ Age } & Male & $262(35 \%)$ \\
\cline { 2 - 3 } & Morethan 30years & $423(56 \%)$ \\
\hline \multirow{2}{*}{ Work Experience } & Less than 30years & $331(44 \%)$ \\
\cline { 2 - 3 } & Morethan 10years & $402(53 \%)$ \\
\cline { 2 - 3 } & Less than 10years & $352(47 \%)$ \\
\hline
\end{tabular}

\subsection{Survey Development}

The researcher used a questionnaire to answer the research questions. The questionnaire consisted of four sections.

The first one focused on CT skills and contained 16 items. The second section of the questionnaire focused on CT instructional strategies and consisted of 15 items. The third one, which focused on CT assessment techniques, consisted of 15 items. The fourth section consisted of 12 items focusing on CT difficulties. Each item was measured using a five-point Likert scale in which 1= never, 2= rarely, 3= sometimes, 4= often, and 5= always.

\subsection{Validity of the instrument}

Nine experts in curriculum and instruction in the College of Education reviewed the questionnaire to ensure the integrity of its interlocutor and items. The researcher modified the questionnaire based on the reviewers' comments. An inter-item correlation test was also used to verify the validity of the questionnaire content. Table 2 shows a high correlation between the statements, the total instrument score, and the relevant category items. That means the questionnaire instrument used in this study is internally valid.

Table 2 shows the questionnaire's Inter-Item Correlations between the statements, the total instrument score, and the relevant category items. 
Table 2: Questionnaire's Inter-Item Correlations

\begin{tabular}{|c|c|c|c|c|c|c|c|}
\hline \multicolumn{2}{|c|}{ CT Skills } & \multicolumn{2}{c|}{ CT Strategies } & \multicolumn{2}{c|}{ CT Assessment } & \multicolumn{2}{c|}{ CT Difficulties } \\
\hline Item & $\begin{array}{c}\text { Index } \\
\text { Correlation }\end{array}$ & Item & $\begin{array}{c}\text { Index } \\
\text { Comelation }\end{array}$ & Item & $\begin{array}{c}\text { Index } \\
\text { Correlation }\end{array}$ & Item & $\begin{array}{c}\text { Index } \\
\text { Correlation }\end{array}$ \\
\hline 1 & $0.668^{*}$ & 1 & $0.657^{*}$ & 1 & $0.744^{*}$ & 1 & $0.747^{*}$ \\
\hline 2 & $0.738^{*}$ & 2 & $0.749^{*}$ & 2 & $0.772^{*}$ & 2 & $0.737^{*}$ \\
\hline 3 & $0.667^{*}$ & 3 & $0.754^{*}$ & 3 & $0.690^{*}$ & 3 & $0.628^{*}$ \\
\hline 4 & $0.819^{*}$ & 4 & $0.569^{*}$ & 4 & $0.698^{*}$ & 4 & $0.762^{*}$ \\
\hline 5 & $0.633^{*}$ & 5 & $0.747^{*}$ & 5 & $0.631^{*}$ & 5 & $0.551^{*}$ \\
\hline 6 & $0.755^{*}$ & 6 & $0.654^{*}$ & 6 & $0.663^{*}$ & 6 & $0.662^{*}$ \\
\hline 7 & $0.693^{*}$ & 7 & $0.557^{*}$ & 7 & $0.641^{*}$ & 7 & $0.648^{*}$ \\
\hline 8 & $0.689^{*}$ & 8 & $0.731^{*}$ & 8 & $0.744^{*}$ & 8 & $0.744^{*}$ \\
\hline 9 & $0.637^{*}$ & 9 & $0.766^{*}$ & 9 & $0.752^{*}$ & 9 & $0.794^{*}$ \\
\hline 10 & $0.739^{*}$ & 10 & $0.635^{*}$ & 10 & $0.787^{*}$ & 10 & $0.647^{*}$ \\
\hline 11 & $0.747^{*}$ & 11 & $0.741^{*}$ & 11 & $0.642^{*}$ & 11 & $0.745^{*}$ \\
\hline 12 & $0.772^{*}$ & 12 & $0.538^{*}$ & 12 & $0.742^{*}$ & 12 & $0.774^{*}$ \\
\hline 13 & $0.599^{*}$ & 13 & $0.606^{*}$ & 13 & $0.709^{*}$ & & \\
\hline 14 & $0.741^{*}$ & 14 & $0.673^{*}$ & 14 & $0.582^{*}$ & & \\
\hline 15 & $0.678^{*}$ & 15 & $0.749^{*}$ & 15 & $0.746^{*}$ & & \\
\hline 16 & $0.563^{*}$ & & & & & & \\
\hline
\end{tabular}

* significant at $\alpha=0.05$

\subsection{Reliability test}

A reliability test was conducted using Cronbach's alpha. The reliability coefficients ranged from 0.790 to 0.813 for the four categories, and the result for the total questionnaire equaled 0.799 , indicating the overall high reliability of scales used in the survey. Table 3 shows the reliability of the study instrument.

Table 3: Summary Statistics of Reliability Test

\begin{tabular}{|c|c|c|}
\hline Category & Statement No. & Cronbach's alpha \\
\hline Items of CT skills & 16 & .813 \\
\hline Items of CT strategies & 15 & .790 \\
\hline Items of CT assessment & 15 & .801 \\
\hline Items of CT difficulties & 12 & .794 \\
\hline Total & 42 & .799 \\
\hline
\end{tabular}




\subsection{Data Collection and Analysis}

Data of this study were collected through the online survey questionnaire to use the Google platform. The questionnaire was distributed in the fall semester of 2019-2020 to 650 social studies teachers 150 supervisors in Kuwait schools. Of the 650 teachers, 638 answers were appropriately replied to the questionnaire. Additionally, of 150 supervisors, 116 replies were considered proper. Each response was shorted its frequency appropriate to four indexed: CT skills, CT teaching strategies, CT assessment techniques, CT difficulties. The study used SPSS released 29 software to analyze the data. The means, standard deviation, and ttest were calculated to finalize the results of the study.

\section{Findings and discussion}

An extensive literature review was conducted to identify CT skills, instructional strategies, and assessment techniques. After analyzing data, the following results were obtained:

\section{Q1. What are critical-thinking skills applied by social studies teachers in Kuwait?}

As shown in Table 4, the overall mean ratings of participants on the 16 items focusing on critical thinking skills applied by social studies teachers during the teaching process were considered the highest mean above 2.99 with a highest standard deviation above 1.0. Thus, the highest mean rating of 4.27 was obtained for Item 2, "Encouraging students to ask questions," Item 1 "Distinguishing correct answers from wrong answers" with a mean of 4.22, Item 6 "Explaining information" with a mean of 3.92, Item 4 "Determining right resources" with a mean of 3.86, Item 5 "Listening to others' views and opinions" with a mean of 3.81, and Item 11 "Distinguishing between facts and opinions" with a mean of 3.80 .

According to the opinion of the participants, the following items received estimates ranging from "sometimes" to "rarely": Item 7 "Analyzing arguments" got a mean of 2.73, Item 9 "Making inferences" with a mean of 2.51, Item 8 "Judging or evaluating performance" with a mean 2.06, Item 12 "Making decisions" had a mean of 2.03, and Item 13 "Solving problems" with a mean of 2.0. That indicates that teachers do not give these skills sufficient attention.

These findings show there is considerable neglect on the part of the teachers in teaching the following critical-thinking skills as evidenced by the following items: Item 3 "Testing hypotheses," which had a mean of 1.46, Item 15 
"Drawing logical conclusions" with a mean of 1.41, Item 14 "Analyzing cause-andeffect relationships" had a mean of 1.38, Item 10 "Thinking chronologically" with a mean of 1.36, and finally Item 16 "Taking different perspectives" with a mean of 1.21.

Teachers are neglecting many critical-thinking skills. The result is consistent with Akingoglu's (2015) findings, who mentioned that research indicates the teaching of CT skills has been problematic, unsuccessful, and generally neglected. This finding may be due to teachers' lack of understanding of the concept and skills of critical thinking. Many research studies have shown that teachers who conceptualized critical thinking and were aware of teaching strategies did a better job teaching thinking skills. This corresponds to Changwong et al. (2018), who indicated that social studies teachers do not have a comprehensive concept of critical thinking and do not have an adequate understanding of critical thinking. Table 4 relates to the first question of the study, which states the following: What critical-thinking skills are applied by social studies teachers in Kuwait?

Table 4: Critical thinking skills applied by social studies teachers.

\begin{tabular}{|c|c|c|c|c|}
\hline No. & Items & M & S.D. & Rank \\
\hline 2 & Encouraging students to ask questions & 4.27 & 1.244 & 1 \\
\hline 1 & Distinguishing correct answers from wrong answers & 4.22 & 1.024 & 2 \\
\hline 6 & Explaining information & 3.92 & 1.242 & 3 \\
\hline 4 & Determining the right resources & 3.86 & 1.443 & 4 \\
\hline 5 & Listening to others' views and opinions & 3.81 & 1.452 & 5 \\
\hline 11 & Distinguishing between factsand opinions & 3.80 & 1.394 & 6 \\
\hline 7 & Analyzing arguments & 2.73 & 1.411 & 7 \\
\hline 9 & Making inferences & 2.51 & 1.441 & 8 \\
\hline 8 & Judging or evaluating performance & 2.06 & 1.693 & 9 \\
\hline 12 & Making decisions & 2.03 & 1.331 & 10 \\
\hline 13 & Solving problems & 2.00 & 1.304 & 11 \\
\hline 3 & Testinghypotheses & 1.46 & 1.562 & 12 \\
\hline 15 & Drawing logical conclusions & 1.41 & 1.441 & 13 \\
\hline 14 & Analyzing cause-and-effect relationships & 1.38 & 1.333 & 14 \\
\hline 10 & Thinking chronologically & 1.36 & 1.066 & 15 \\
\hline 16 & Taking different perspectives & 1.21 & 1.292 & 16 \\
\hline
\end{tabular}


Table 5 related to the first hypothesis, which states the following:

H1: There are no significant differences at the level of significance (.05) between teachers and instructional supervisors regarding applying critical thinking skills due to occupation, gender, age, or experience.

It is shown in Table 5 that the value of the t-test related to the occupation is 1.897 , and the level of significance is $.318>.05$. It means that there are no significant differences between the responses of the participants due to the occupation. As for gender, the t-test value is 1.059, and the significance level is .344 $>.05$, indicating no statistically significant differences between the participants due to gender. As for age, the t-test value is 1.366 , and the significance level is $.373>$ .05 , indicating no statistically significant differences related to age. Finally, the value of the t-test related to experience is 1.410, and the level of significance is .390> 05 . It was pointed out that there was no statistical significance associated with this experience. Therefore, the first null hypothesis is acceptable.

Table 5: T-test results and level of significance related to the CT Skills

\begin{tabular}{|c|c|c|c|c|c|c|}
\hline Types & Participants & $\mathbf{N}$ & $M$ & S/D & T-value & Significance level \\
\hline \multirow[t]{2}{*}{ Occupation } & Teacher & 638 & 2.211 & 1.322 & \multirow[t]{2}{*}{1.897} & \multirow[t]{2}{*}{.318} \\
\hline & Supervisor & 116 & 2.091 & 1.215 & & \\
\hline \multirow[t]{2}{*}{ Gender } & $\mathrm{F}$ & 492 & 2.334 & 2.885 & \multirow[t]{2}{*}{1.059} & \multirow[t]{2}{*}{.344} \\
\hline & $M$ & 262 & 2,021 & 1.114 & & \\
\hline \multirow[t]{2}{*}{ Age } & $\begin{array}{c}\text { More than } \\
30 \\
\end{array}$ & 423 & 2.030 & 1.057 & \multirow[t]{2}{*}{1.366} & \multirow[t]{2}{*}{.373} \\
\hline & $\begin{array}{c}\text { Lessthan } \\
30\end{array}$ & 331 & 2.100 & 1.313 & & \\
\hline \multirow{2}{*}{$\begin{array}{c}\text { Work } \\
\text { Experience }\end{array}$} & $\begin{array}{c}\text { Morethan } \\
10 \\
\end{array}$ & 402 & 2.212 & $\begin{array}{c}6 \\
1.101 \\
\end{array}$ & \multirow[t]{2}{*}{1.410} & \multirow[t]{2}{*}{.390} \\
\hline & $\begin{array}{l}\text { Less Than } \\
10\end{array}$ & 352 & 2.096 & 1.442 & & \\
\hline
\end{tabular}

* significant at $\alpha=0.05$

Table 6 relates to the second question of the study, which states the following:

\section{Q2: What instructional strategies are used by social studies teachers to foster critical-thinking skills?}

Table 6 shows that most teachers used traditional teaching methods that relied on teacher-centered rather than student-centered approaches, as shown in Item 1 , which had $M=4.45$ and $S D=1.142$. A set of strategies was applied to a moderate degree, such as in Items 3,6,13,5 with $M=2.24-M 2.06$ such as "group 
work and discussions, writing activities, oral or visual presentations, and cooperative learning."

The following instructional strategies got very low means ranging from $M=1.80$ to $M=1.05$ : Explicit instruction, inquiry-based learning, constructivist learning methods, simulation and role-playing, debate competitions and argument mapping, project-based activities, network communication, brainstorming, handon activities, collaborative learning, and problem-solving. As is well known, the use of the previously mentioned instructional strategies contributes to developing critical-thinking skills among students. In addition, Hohmann and Jayanti(2021) noted that classroom teachers should have activities that promote increased critical thinking, such as analyzing, criticizing, and initiating ideas to derive factual conclusions.

Table 6: Critical thinking teaching strategies

\begin{tabular}{|c|l|c|c|c|}
\hline No. & \multicolumn{1}{|c|}{ Items } & M & S.D. & Rank \\
\hline 1 & $\begin{array}{l}\text { Traditional teaching methods relied on teacher-centered } \\
\text { approaches }\end{array}$ & 4.45 & 1.142 & 1 \\
\hline 3 & Group workand discussions & 2.24 & 1.121 & 2 \\
\hline 6 & Writing activities & 2.12 & 1.252 & 3 \\
\hline 13 & Oral or visual presentations & 2.06 & 1.343 & 4 \\
\hline 5 & Cooperative learning & 2.01 & 1.422 & 5 \\
\hline 11 & Explicit instruction & 1.80 & 1.352 & 6 \\
\hline 2 & Inquiry-based learning & 1.77 & 1.420 & 7 \\
\hline 8 & Constructivist learning methods & 1.59 & 1.331 & 8 \\
\hline 14 & Simulation and role-playing & 1.55 & 1.461 & 9 \\
\hline 7 & Debate competitions and argument mapping & 1.51 & 1.223 & 10 \\
\hline 9 & Project-based activities & 1.47 & 1.366 & 11 \\
\hline 4 & Network communication & 1.42 & 1.480 & 12 \\
\hline 10 & Brainstorming & 1.26 & 1.111 & 13 \\
\hline 12 & Hands-on activities & 1.14 & 1.301 & 14 \\
\hline 15 & Collaborative learning and problem-solving & 1.05 & 1.094 & 15 \\
\hline
\end{tabular}

Table 7 related to the second null hypothesis:

H2: There are no significant differences at the level of significance (.05) between teachers and instructional supervisors regarding strategies for teaching critical thinking skills due to occupation, gender, age, or experience.

It is shown in Table 7 that the value of the t-test related to the occupation is 1.789 , and the level of significance is $.316>.05$. It means that there are no significant differences between the responses of the participants due to the occupation. As for gender, the t-test value is 1.153, and the significance 
level is .295 > .05, indicating no statistically significant differences between the participants due to gender. As for age, the t-test value is 1.267 , and the significance level is $.321>.05$, indicating no statistically significant differences related to age. Finally, the value of the t-test related to experience is 1.390 , and the level of significance is $.365>.05$. It was pointed out that there was no statistical significance associated with this experience. Therefore, the second null hypothesis is acceptable.

Table 7: T-test results and level of significance related to the CT Teaching Strategies

\begin{tabular}{|c|c|c|c|c|c|c|}
\hline Types & Participants & $\mathbf{N}$ & $M$ & S/D & T-value & $\begin{array}{c}\text { Significance } \\
\text { level }\end{array}$ \\
\hline \multirow[t]{2}{*}{ Occupation } & Teacher & 638 & 2.111 & 1.322 & \multirow[t]{2}{*}{1.789} & \multirow[t]{2}{*}{.316} \\
\hline & Supervisor & 116 & 1.891 & 1.215 & & \\
\hline \multirow[t]{2}{*}{ Gender } & $\mathrm{F}$ & 492 & 2.334 & 2.885 & \multirow[t]{2}{*}{1.153} & \multirow[t]{2}{*}{.295} \\
\hline & $M$ & 262 & 2,021 & 1.114 & & \\
\hline \multirow[t]{2}{*}{ Age } & $\begin{array}{c}\text { Morethan } \\
30\end{array}$ & 423 & 2.030 & 1.057 & \multirow[t]{2}{*}{1.267} & \multirow[t]{2}{*}{.321} \\
\hline & $\begin{array}{c}\text { Lessthan } \\
30\end{array}$ & 331 & 2.100 & 1.313 & & \\
\hline \multirow{2}{*}{$\begin{array}{c}\text { Work } \\
\text { Experience }\end{array}$} & $\begin{array}{c}\text { Morethan } \\
10 \\
\end{array}$ & 402 & 2.212 & 1.101 & \multirow[t]{2}{*}{1.390} & \multirow[t]{2}{*}{.365} \\
\hline & $\begin{array}{c}\text { Less Than } \\
10\end{array}$ & 352 & 2.096 & 1.442 & & \\
\hline
\end{tabular}

* significant at $\alpha=0.05$

Table 8 related to the third question of the study, which states the following: Q3: What assessment techniques are used by social studies teachers when teaching critical-thinking skills?

Most of the social studies teachers used traditional methods to assess student's critical-thinking skills. Table 8 shows that teachers' most used assessment techniques are those in Items 2,3,4 and 1, which are: "True/false, Multiple-choice, Open-ended, and Essay questions." These items obtained high means ranging from 4.27 to 4.06 . These techniques focus on remembering facts and do not measure student critical-thinking skills. In contrast, teachers rarely used the following assessment tools: In-class presentations, speaking exercises, observation, journal, and writing samples. 
Table 8: Critical-thinking assessment techniques

\begin{tabular}{|c|l|c|c|c|}
\hline No. & \multicolumn{1}{|c|}{ Items } & Mean & S.D. & Rank \\
\hline 2 & True/false & 4.27 & 1.244 & 1 \\
\hline 3 & Multiple-choice & 4.22 & 1.024 & 2 \\
\hline 4 & Open-ended questions & 4.12 & 1.242 & 3 \\
\hline 1 & Essay questions & 4.06 & 1.443 & 4 \\
\hline 9 & In-class presentations & 2.18 & 1.452 & 5 \\
\hline 8 & Speaking exercises & 2.12 & 1.394 & 6 \\
\hline 5 & Observation & 2.10 & 1.411 & 7 \\
\hline 13 & Journal and writing samples & 2.05 & 1.441 & 8 \\
\hline 7 & Open-ended problem types & 1.46 & 1.693 & 9 \\
\hline 15 & Panelsand simulations & 1.37 & 1.302 & 10 \\
\hline 11 & Laboratory reports & 1.30 & 1.331 & 11 \\
\hline 6 & Videotapes of studentinteractions & 1.25 & 1.125 & 12 \\
\hline 12 & Students' portfolios & 1.18 & 1.401 & 13 \\
\hline 14 & Extended Performance & 1.11 & 1.511 & 14 \\
\hline 10 & Long-term projects & 1.07 & 1.447 & 15 \\
\hline
\end{tabular}

Table 9 related to the third null hypothesis, which states the following:

H3: There are no significant differences at the level of significance (.05) between teachers and instructional supervisors regarding critical thinking assessment due to occupation, gender, age, or experience.

It is shown in Table 9 that the value of the t-test related to the occupation is 1.187 , and the level of significance is $.320>.05$. It means that there are no significant differences between the responses of the participants due to the occupation. As for gender, the t-test value is 1.216, and the significance level is .296 $>.05$, indicating no statistically significant differences between the participants due to gender. As for age, the t-test value is 1.242 , and the significance level is $.319>$ .05 , indicating no statistically significant differences related to age. Finally, the value of the t-test related to experience is 1.383 , and the level of significance is $.371>.05$. It was pointed out that there was no statistical significance associated with this experience. Therefore, the third null hypothesis is acceptable. 
Table 9: T-test results and level of significance related to the CT Assessment

\begin{tabular}{|c|c|c|c|c|c|c|}
\hline Types & Participants & $\mathbf{N}$ & $M$ & S/D & T-value & $\begin{array}{c}\text { Significance } \\
\text { level }\end{array}$ \\
\hline \multirow[t]{2}{*}{ Occupation } & Teacher & 638 & 2.257 & 1.322 & \multirow[t]{2}{*}{1.187} & \multirow[t]{2}{*}{.320} \\
\hline & Supervisor & 116 & 1.998 & 1.215 & & \\
\hline \multirow[t]{2}{*}{ Gender } & $\mathrm{F}$ & 492 & 2.334 & 2.885 & \multirow[t]{2}{*}{1.216} & \multirow[t]{2}{*}{.296} \\
\hline & $M$ & 262 & 2,021 & 1.114 & & \\
\hline \multirow[t]{2}{*}{ Age } & $\begin{array}{c}\text { Morethan } \\
30\end{array}$ & 423 & 2.030 & 1.057 & \multirow[t]{2}{*}{1.242} & \multirow[t]{2}{*}{.319} \\
\hline & $\begin{array}{c}\text { Less than } \\
30\end{array}$ & 331 & 2.100 & 1.313 & & \\
\hline \multirow[t]{2}{*}{$\begin{array}{c}\text { Work } \\
\text { Experience }\end{array}$} & $\begin{array}{c}\text { Morethan } \\
10\end{array}$ & 402 & 2.212 & 1.101 & \multirow[t]{2}{*}{1.383} & \multirow[t]{2}{*}{.371} \\
\hline & $\begin{array}{l}\text { Less Than } \\
10\end{array}$ & 352 & 2.096 & 1.442 & & \\
\hline
\end{tabular}

* significant at $\alpha=0.05$

Table 10 related to the fourth question:

Q4: What difficulties are social studies teachers facing while teaching criticalthinking skills?

Regarding the difficulties social studies teachers face in Kuwait when teaching critical thinking, respondents agreed on the challenges shown in Table 10. These findings are consistent with other researchers (Nussbaum et al., 2021; Odebiyi \& Odebiyi, 2021; Güven \& Gulbahar, 2020). All difficulties mentioned in Table 10 obtained high means that ranged between 4.77-3.27. And there was agreement among the participants on it. Thus, there is no doubt that these difficulties hinder teachers when teaching critical thinking skills.

Table 10: Critical-thinking difficulties.

\begin{tabular}{|c|c|c|c|c|}
\hline No. & Items & Mean & S.D. & Rank \\
\hline 5 & Unclear conceptualization of critical thinking & 4.77 & 1.433 & 1 \\
\hline 4 & Lackof proper assessment & 4.72 & 1.462 & 2 \\
\hline 1 & Lackof teachertraining & 4.71 & 1.282 & 3 \\
\hline 6 & Limited resources & 4.66 & 1.412 & 4 \\
\hline 3 & Lack of administrative leadership & 4.61 & 1.244 & 5 \\
\hline 10 & Communicationand supportstructures & 4.50 & 1.391 & 6 \\
\hline 8 & Lackof promoting social action in the schools & 4.43 & 1.211 & 7 \\
\hline 9 & Lackof democracy skillsinthecurriculum & 3.88 & 1.440 & 8 \\
\hline 2 & Instructional timeavailable to teachers & 3.76 & 1.671 & 9 \\
\hline 11 & Theteacher'sability to affectcurriculum & 3.68 & 1.834 & 10 \\
\hline 12 & Limited conceptions of diversity & 3.53 & 1.079 & 11 \\
\hline 7 & Theamountof student tracking practiced in school & 3.27 & 1.388 & 12 \\
\hline
\end{tabular}


Table 11 related to the fourth null hypothesis, which states:

H4: There are no significant differences at the level of significance (.05) between teachers and instructional supervisors related to the difficulties encountered in teaching critical thinking skills due to occupation, gender, age, or experience.

It is shown in Table 11 that the value of the t-test related to the occupation is 1.206 , and the level of significance is $.381>.05$. It means that there are no significant differences between the responses of the participants due to the occupation. As for gender, the t-test value is 1.225 , and the significance level is .289 $>.05$, indicating no statistically significant differences between the participants due to gender. As for age, the t-test value is 1.310, and the significance level is .321 > .05 , indicating no statistically significant differences related to age. Finally, the value of the t-test related to experience is 1.378, and the level of significance is .381 > 05 . It was pointed out that there was no statistical significance associated with this experience. Therefore, the fourth null hypothesis is acceptable.

Table 11:T-test results and level of significance related to the CT Difficulties

\begin{tabular}{|c|c|c|c|c|c|c|}
\hline Types & Participants & $\mathbf{N}$ & $M$ & S/D & T-value & $\begin{array}{c}\text { Significance } \\
\text { level }\end{array}$ \\
\hline \multirow[t]{2}{*}{ Occupation } & Teacher & 638 & 4.257 & 1.431 & \multirow[t]{2}{*}{1.206} & \multirow[t]{2}{*}{.381} \\
\hline & Supervisor & 116 & 4.198 & 1.216 & & \\
\hline \multirow[t]{2}{*}{ Gender } & $\mathrm{F}$ & 492 & 4.234 & 2.885 & \multirow[t]{2}{*}{1.225} & \multirow[t]{2}{*}{.289} \\
\hline & $M$ & 262 & 4.201 & 1.114 & & \\
\hline \multirow[b]{2}{*}{ Age } & $\begin{array}{c}\text { Morethan } \\
30\end{array}$ & 423 & 4.130 & 1.057 & \multirow[t]{2}{*}{1.310} & \multirow[t]{2}{*}{.321} \\
\hline & $\begin{array}{c}\text { Less than } \\
30\end{array}$ & 331 & 4.200 & 1.313 & & \\
\hline \multirow{2}{*}{$\begin{array}{c}\text { Work } \\
\text { Experience }\end{array}$} & $\begin{array}{c}\text { Morethan } \\
10 \\
\end{array}$ & 402 & 4.202 & 1.101 & \multirow[t]{2}{*}{1.378} & \multirow[t]{2}{*}{.381} \\
\hline & $\begin{array}{c}\text { Less Than } \\
10\end{array}$ & 352 & 4.096 & 1.442 & & \\
\hline
\end{tabular}

* significant at $\alpha=0.05$

\section{Discussion Summary}

The following is a summary of the findings of the study:

Most social studies teachers in Kuwait focus on cognitive skills associated with critical thinking and neglect dispositional skills. Teachers care about the following skills: asking questions, distinguishing right and wrong answers, explaining information, determining right resources, listening to others' views and opinions, and distinguishing between facts and opinion. Conversely, there is slight 
or no interest in analyzing arguments, making inferences, judging or evaluating performance, making decisions, solving problems, testing hypotheses, drawing logical conclusions, analyzing cause-and-effect relationships, thinking chronologically, or taking different perspectives.

For the instructional strategies used by social studies teachers to enhance critical-thinking skills, we find that teachers still use teacher-centered rather than student-centered methods. For example, some teachers applied group work, group discussions, writing activities, oral or visual presentations, and cooperative learning. However, the vast majority did not use educationally agreed-upon strategies, such as explicit instruction, inquiry-based learning, constructivist learning methods, simulation, role-playing, debate competitions, project-based activities, network communication, argument mapping, fieldwork, brainstorming, hand-on activities, collaborative learning, and problem-solving (Celik, 2021).

One of the most important results of this study is that most teachers do not have a broad conception of critical thinking. Therefore, one of the conditions necessary to foster critical thinking is first to have competent teachers. (Arifin, 2020).

Studies have also shown that teachers who guided their students during activities, conceptualized critical thinking; were aware of strategies to teach critical thinking; and introduced the subject with demonstrations, pictures, maps, examples, or experiments did better teaching thinking skills (Chen, 2019).

Concerning the difficulties faced by teachers of social studies in Kuwait when teaching critical thinking, the following obstacles have emerged: unclear conceptualization of critical thinking, lack of proper assessment, lack of teacher training, limited resources, lack of administrative leadership, limited conceptions of diversity, missing communication and support structures, lack of promoting social action in the schools, lack of democracy skills in the curriculum, instructional time available to teachers.

\section{Recommendations}

This study's findings resulted in the following recommendations:

1. Increase the importance of training and preparation programs for social studies teachers in college education to apply critical-thinking skills, instructional strategies, and assessment techniques. Develop teacher professional development programs and deliver workshops focusing on 
critical-thinking skills, instruction and assessment, and integration into teacher preparation and certification programs.

2. Pay attention to staff development and in-service training for teachers on critical-thinking instructional methods and modern assessment techniques.

3. Develop social studies curricula to include activities, skills, teaching, and assessment techniques.

4. Encourage teachers to focus on the following CT skills: analyzing arguments, making inferences, judging or evaluating performance, making decisions, solving problems, testing hypotheses, drawing logical conclusions, analyzing cause-and-effect relationships, thinking chronologically, and adopting different perspectives.

5. Encourage teachers to utilize instructional strategies to foster CT. That could include group work and discussions, writing activities, presentations, cooperative learning, explicit instruction, inquiry learning, constructivist learning methods, simulation, and role-playing. Other strategies might involve debate competitions, project-based activities, network communication, argument mapping, fieldwork, brainstorming, hands-on activities, collaborative learning, and problem-solving.

6. Encourage teachers to apply the following assessment techniques in CT: in-class presentations, speaking exercises, observation, journal and writing samples, open-ended problem types, panels and simulations, laboratory reports, videotapes of student interactions, portfolios, and performance in extended, long-term projects. In addition, standardized tests like the California Critical-Thinking Skills Test, the Watson-Glaser CT Appraisal, and the Ennis-Weir CT Essay Test could be administered.

7. Overcome the difficulties that impede social studies teachers from achieving the desired educational objectives of teaching critical-thinking skills.

Teaching critical thinking is a difficult task, and there are various problems in achieving this goal. Among the barriers are the ambiguous definitions of $\mathrm{CT}$, the lack of organized sequence in teaching $\mathrm{CT}$, the threatening nature of CT practice, the lack of proper assessment, and the lack of teacher training. However, these problems have solutions, some of which provide teachers with specific training courses, continued practice, using critical challenges, considering different levels of $\mathrm{CT}$, and encouraging a positive 
attitude toward the process. Critical thinking, if implemented, would greatly influence people's lives.

Given the lack of research on critical thinking in social studies curricula in Kuwait, the researcher suggests conducting more studies on the degree to which social studies curricula include critical thinking skills.

\section{Conclusion}

This study's findings have implications for curriculum developers, university educators, and trainers offering in-service programs to teachers. First, curriculum developers need to cooperate and collaborate more with teachers in developing the kinds of course materials (input and tasks) that are most likely to address students. Additionally, both teacher education and in-senvice programs should educate teachers to continually consider the appropriateness of course materials to their students and skillfully initiate bridging any gap between them. Finally, teachers should be provided with opportunities to develop a sense of resourcefulness during their university education and teaching careers.

This study revealed that critical-thinking skills, instructional strategies, and assessment techniques should be utilized more in social studies classrooms to promote critical thinking. However, further studies are needed regarding applying critical-thinking skills to other subjects, such as science and mathematics, in Kuwaiti schools.

\section{Acknowledgment}

The author is very thankful to all the associated personnel in any reference that contributed to/for this research. 


\section{References}

1. Akinoglu, O., \& Baykin, Y. (2015). Raising critical thinkers: Critical thinking skills in secondary social studies curricula in Turkey. The Anthropologist, 20(3), 616624.

2. Antonova, S., Pletyago, T., \& Ostapenko, A. (2020). Fostering Critical Thinking Skills in European and Asian Higher Education Institutions. MIER Journal of Educational Studies Trends \& Practices, 138-150.

3. Arifin, E. G. (2020). Problem Based Learning to Improve Critical Thinking. In Social, Humanities, and Educational Studies (SHEs): Conference Series (Vol. 3, No. 4, pp. 98-103). DOI: https://doi.org/10.20961/shes.v3i4.53288

4. Bermudez, A. (2015). Four tools for critical inquiry in history, social studies, and civic education. Revista de Estudios Sociales, (52), 102-118.

5. Bekbayeva, Z. S., Galiyev, T. T., Albytova, N., Zhazykbayeva, Z. M., \& Mussatayeva, A. B. (2021). Fostering post-secondary vocational students' critical thinking through multi-level tasks in learning environments. World Journal on Educational Technology: Current Issues, 13(3), 397-406.

6. Celik, S. (2021). Teacher education program supporting critical thinking skills: a case of primary school teachers. Amazonia Investiga, 10(41), 188-198.

7. Changwong, K., Sukkamart, A., \& Sisan, B. (2018). Critical thinking skill development: Analysis of a new learning management model for Thai high schools. Journal of International Studies, 11(2).

8. Chen, L H. (2019). Book Review: National curriculum standards for social studies: A framework for teaching, learning, and assessment \& college, career, and civic life (C3) Framework for Social Studies State Standards. Jiaoyu Yanjiu Jikan= Bulletin of Educational Research, 65(2), 117-135.

9. Creswell, J. W. (2021). A concise introduction to mixed methods research. SAGE publications.

10. Fajrianti, F., Hartono, H., \& Nugroho, S. E. (2021). The Fourth Graders' Critical Thinking Skills on Social Study Lesson. Educational Management.

11. Güven, I., \& Gulbahar, Y. (2020). Integrating Computational Thinking into Social Studies. The Social Studies, 111(5), 234-248.

12. Heberle, A. E., Rapa, L. J., \& Farago, F. (2020). Critical consciousness in children and adolescents: A systematic review, critical assessment, and recommendations for future research. Psychological Bulletin, 146(6), 525. 
13. Hidayatul, A., Nasution, N., \& Nugroho, P. H. (2020). The Impact of Discovery Learning Models on The Critical Thinking Ability of Students at MiddleSchool. International Journal for Educational and Vocational Studies, 2(4).

14. Jayanti, I. A. M. T. D. (2021). The Use of Discovery Learning in Improving Students' Critical Thinking Ability. The Art of Teaching English as a Foreign Language, 1(2), 13-17.

15. Kayaalp, F., Meral, E., Şimşek, U., \& ŞAHIN, İ. F. (2020). A search for a method to improve critical thinking skills in social studies teaching: Writing-to-learn. Review of International Geographical Education Online, 10(3), 400-430.

16. Keleman, M., Rasul, M. S., \& Jalaludin, N. A. (2021). Assessment of Higher Order Thinking Skills Through Stem Integration Project-Based Learning for Elementary Level.

17. Kopotun, I. M., Durdynets, M. Y., Teremtsova, N. V., Markina, L. L., \& Prisnyakova, L M. (2020). The use of smart technologies in the professional training of students of the Law Departments for the development of their critical thinking. International Journal of Learning, Teaching and Educational Research, 19(3), 174-187.

18. Kozikoglu, I. (2019). Investigating Critical Thinking in Prospective Teachers: Metacognitive Skills, Problem Solving Skills and Academic Self-Efficacy. Journal of Social Studies Education Research, 10(2), 111-130.

19. Lennon, S. (2017). Questioning for Controversial and Critical Thinking Dialogues in the Social Studies Classroom. Issues in Teacher Education, 26(1), 3-16.

20. Liu, T., Yu, X., Liu, M., Wang, M., Zhu, X., \& Yang, X. (2021). A mixed method evaluation of an integrated course in improving critical thinking and creative self-efficacy among nursing students. Nurse Education Today, 105067.

21. Maksum, A., Widiana, I. W., \& Marini, A. (2021). Path Analysis of SelfRegulation, Social Skills, Critical Thinking and Problem-Solving Ability on Social Studies Learning Outcomes. International Journal of Instruction, 14(3).

22. Mendoza, C. R. (2021). Critical Thinking in Basic Education Students: An Inventive Analysis. Asian Journal of Education and Social Studies, 1-9.

23. Miguel-Revilla, D., Martínez-Ferreira, J. M., \& Sánchez-Agustí, M. (2020). Assessing the digital competence of educators in social studies: An analysis in initial teacher training using the TPACK-21 model.Australasian Journal of Educational Technology, 36(2), 1-12. 
24. Ministry of Education, (2019). Education Statistical Buletin. Planning Department. Kuwait. https://www.moe.edu.kw/Pages/statistics.aspx

25. Nurhayati, D. A. W., Putranto, A., Marwa, D. M., \& Purwowidodo, A. (2020, May). Effect of Thinking Skill-Based Inquiry Learning Method on Learning Outcomes of Social Studies: A Quasi-Experimental Study on Grade VIII Students of MTSN 6 Tulungagung. In IOP Conference Series: Earth and Environmental Science (Vol. 485, No. 1, p. 012073). IOP Publishing.

26. Nussbaum, M., Barahona, C., Rodriguez, F., Guentulle, V., Lopez, F., VazquezUscanga, E., \& Cabezas, V. (2021). Taking critical thinking, creativity and grit online. Educational Technology Research and Development, 69(1), 201-206.

27. Odebiyi, O. M., \& Odebiyi, A. T. (2021). Critical thinking in social contexts: A trajectory analysis of states' K-5 social studies content standards. The Journal of Social Studies Research.

https://doi.org/10.1016/j.jssr.2021.05.002

28. Purnawati, R. R., Susanti, M. M. I., \& Rustamti, M. I. (2021). Improving Critical Thinking Skills and Creativity of Fourth Grade Students in Social Science Using Inquiry Based Learning Model. JECA (International Journal of Education and Curriculum Application), 4(2), 75-82.

29. Saadah Hamdi Suwaidan, D., \& Radeh, N. A. R. F. A. (2021). The Effectiveness Of Divergent Thinking Strategies In Developing Deep Understanding Skills When Teaching Second Intermediate Class Students The Social Studies. Psychology and Education Journal, 58(1), 2146-2157.

30. Samaras, S. A., Adkins, C. L, \& White, C. D. (2021). Developing critical thinking skills: Simulations vs. cases. Journal of Education for Business, 1-7.

31. SawitreePipitgool, P. P., \& SomkiatTuntiwongwanich, A. N. (2021). Enhancing Student Computational Thinking Skills by use of a Flipped-Classroom Learning Model and Critical Thinking Problem-Solving Activities: A Conceptual Framework. Turkish Journal of Computer and Mathematics Education (TURCOMAT), 12(14), 1352-1363.

32. Silviariza, W. Y. Sumarmi., \& Handoyo, B.(2021). Improving Critical Thinking Skills of Geography Students with Spatial Problem Based Learning (SPBL). International Journal of Instruction, 14(3), 133-152. 
33. Simanjuntak, M. P., Hutahaean, J., Marpaung, N., \& Ramadhani, D. (2021). Effectiveness of Problem-Based Learning Combined with Computer Simulation on Students' Problem-Solving and Creative Thinking Skills. International Journal of Instruction, 14(3).

34. Stanley, T. L (2017). Increasing students' critical thinking and improving performance in elementary social studies classroom (Doctoral dissertation, Capella University).

35. Thonney, T., \& Montgomery, J. C. (2019). Defining critical thinking across disciplines: An analysis of community college faculty perspectives. College Teaching, 67(3), 169-176.

36. Thornton, S. J. (2017). A concise historiography of the social studies. The Wiley handbook of social studies research, 9-41.

37. Qomar, N., Sumantri, M. S., Marini, A., \& Adiansha, A. A. (2019, January). The Influence of Learning Methods on Students' Critical Thinking: A Case at Social Studies. In 1st International Conference on Innovation in Education (IColE 2018) (pp. 251-256). Atlantis Press.

38. Warsah, I., Morganna, R., \& Uyun, M. (2021). The Impact of Collaborative Learning on Learners' Critical Thinking Skills.International Journal of Instruction, 14(2), 443-460. 